\title{
Effect of Parathyroid Hormone on Osteoclasts in Organ-cultured Medullary Bone.
}

\author{
Toshie Sugiyama and Seiji Kusuhara* \\ Graduate School of Science and Technology \\ ${ }^{*}$ Department of Animal Science, Faculty of \\ Agricultute, Niigata University, \\ Niigata 950-21, Japan
}

\begin{abstract}
The enzyme activity and ultrastructure of osteoclasts in medullary bone cultured in the presence of parathyroid hormone (PTH) were examined using laying hens during the formative phase of the bone when an egg was in the magnum of the oviduct. Before and after the culturing in the absence of PTH, osteoclasts on the surface of medullary bone showed moderate activity for both acid phosphatase (ACP) and succinate dehydrogenase $(\mathrm{SDH})$, and strong lactate dehydrogenase (LHD) activity. These cells lacked ruffled borders adjacent to the bone matrix. On the contrary, in the presence of PTH, ACP and SDH activity in osteoclasts increased after 3 hours of culture. Ruffled bordes also apperared at the peripheral cytoplasm apposed to the bone. After 12 hours of culture, the area of the ruffled borders further increased. After 24 hours of culture, almost all the osteoclasts had well-developed ruffled borders. These results suggest that PTH stimulates osteoclastic resorption in the medullary bone of laying hens during the formative phase of the bone.
\end{abstract}

(Jpn. Poult. Sci., 31 : 392-399, 1994)

Key words : osteoclast, parathyroid hormone, medullary bone, culture, laying hen

\section{Introduction}

Medullary bone is specific to female birds and supplies the calcium for the formation of egg shell (MUELLER et al., 1964). In the medullary bone, osteoclasts cease and accelerate bone resorption repeatedly during the egg-laying cycle (MiLLER, 1977, 1981 ; van de Velde et al., 1984b ; Sugiyama and Kusuhara, 1993). Osteoclasts cease bone resorption during the formative phase of the bone when an egg is in the magnum or the isthmus of the oviduct. During the resorptive phase of the bone when an egg enters into the shell gland of the oviduct and the egg shell is formed, the osteoclasts resorb bone and supply the calcium for egg shell formation. The factors which regulate the osteoclastic resorption of medulary bone, however, have not been clarified yet.

For mammals, it is well known that parathyroid hormone (PTH) stimulates bone resorption and maintains calcium homeostasis in interaction with calcitonin (WendelaAr Bonga and Pang, 1991). For birds, it is also suggested that PTH plays an important role in maintaining calcium metabolism (DE BERNARD et al., 1980 ; LUCK et al., 1980). VAN DE VELDE et al. (1984 a) and Singh et al. (1986) reported that circulating PTH

Received Mar. 10, 1994 
levels fluctuate during the egg-laying cycle, presuming that PTH effects the osteoclastic bone resorption in medullary bone. In addition, Kusuhara (1982) demonstrated that PTH stimulates osteoclastic bone resorption in medullary bone developed by the administration of sexual hormones. Also, it is suggested that following the PTH administration, inactive medullary bone osteoclasts rapidly develop ruffled borders and commence bone resorption (Miller, 1978, 1985 ; Miller et al., 1984). These reports were, however, carried out in vivo. It is difficult to explore the direct effects of PTH on bone tissues and the stimulation of osteoclastic bone resorption in intact animals because PTH promotes the synthesis of 1, 25-dihydroxycholecalciferol in the kidneys (GARABEDIAN et al., 1972). This 1,25-dihydroxycholecalciferol stimulates osteoclastic bone resporption (Holtrop and RAISZ, 1979 ; Holtrop et al., 1981).

In the present study, the effect of PTH on osteoclastic bone resorption was examined in laying hens during the formative phase of the bone using the medullary bone culture system reported previously (SugiYama et al., 1991, 1992).

\section{Materials and Methods}

Laying White Leghorn hens were killed by decapitation when an egg was in the magnum of the oviduct (3 hours after oviposition). The femurs were immediately dissected and transferred under sterile conditions. The epiphyses were removed and the diaphyses were split lengthwise. Medullary bone fragments were excised from the marrow cavity in PBS ( $\mathrm{pH} 7.4$ ) and cut into $2-3 \mathrm{~mm}$ cubes. These fragments were washed in a culture medium, placed on Gelman filters suppoted by stainless steel mesh platforms, and cultured for 24 hours. The culture medium consisted of a FitToNJACKSON modified BGJb supplemented with $10 \%$ heat-inactivated fetal calf serum (Gibco), streptomycinsulfate (Meiji Seika, $100 \mu \mathrm{g} / \mathrm{ml}$ ), and penicillin G potassium (Meiji Seika $; 100 \mathrm{IU} / \mathrm{ml})$. The test culture medium was supplemented with synthetic human PTH (1-34) (Asahi Kasei ; $5 \mathrm{U} / \mathrm{ml}$ ). Both the test and control cultures were gassed with $95 \%$ air and $5 \% \mathrm{CO}_{2}$ and maintained in a humidified incubator at $37^{\circ} \mathrm{C}$.

Bone fragments were taken $0,3,6,12$ and 24 hours of culture. For enzyme histochemistry, some of the fragments were decalcified in a 5\% EDTA solution (pH 7.4) at $4^{\circ} \mathrm{C}$ and frozen in O.C.T. Compound (Miles Lab. Inc.). The specimens were sectioned at a thickness $7 \mu \mathrm{m}$ using a cryostat. Acid phosphatase (ACP) and both succinate dehydrogenase (SDH) and lactate dehydrogenase ( $\mathrm{LDH}$ ) activity were detected by the method of BARKA (1960) and the BARKA and ANDERSON (1963) method, respectively. The other bone fragments were fixed with a $2 \%$ paraformaldehyde- $2.5 \%$ glutaraldehyde mixture in a $0.1 \mathrm{M}$ phosphate buffer $(\mathrm{pH} 7.4)$ for 48 hours at $4^{\circ} \mathrm{C}$ for electron microscopical observation. After fixation, they were decalcified in a 5\% EDTA solution ( $\mathrm{pH} 7.4)$ at $4^{\circ} \mathrm{C}$, postfixed with $1 \%$ osmium tetroxide in a $0.1 \mathrm{M}$ cacodylate buffer ( $\mathrm{pH} 7.4$ ), dehydrated in graded alcohols, and embedded in Quetol 812. The specimens were trimmed and sectioned. Sections were stained with uranyl acetate and lead citrate, and observed with a JEOL $100 \mathrm{~B}$ electron microscope. 
Table 1. Effect of PTH on the enzyme activity of osteoclasts in cultured medullary bone of laying hens when an egg was in the magnum

\begin{tabular}{lcccccc}
\hline \hline \multirow{2}{*}{ Treatment } & Enzyme & \multicolumn{5}{c}{ Culture period (hours) } \\
\cline { 3 - 6 } & & 0 & 3 & 6 & 12 & 24 \\
\hline \multirow{3}{*}{ Control } & $\mathrm{ACP}$ & ++ & ++ & ++ & ++ & ++ \\
& $\mathrm{SDH}$ & ++ & ++ & ++ & ++ & + \\
& $\mathrm{LDH}$ & +++ & +++ & +++ & +++ & +++ \\
\hline \multirow{3}{*}{ PTH } & $\mathrm{ACP}$ & & +++ & +++ & +++ & +++ \\
& SDH & & +++ & +++ & +++ & +++ \\
& LDH & & +++ & +++ & +++ & +++ \\
\hline
\end{tabular}

+++ : strong, ++ : moderate, + : weak

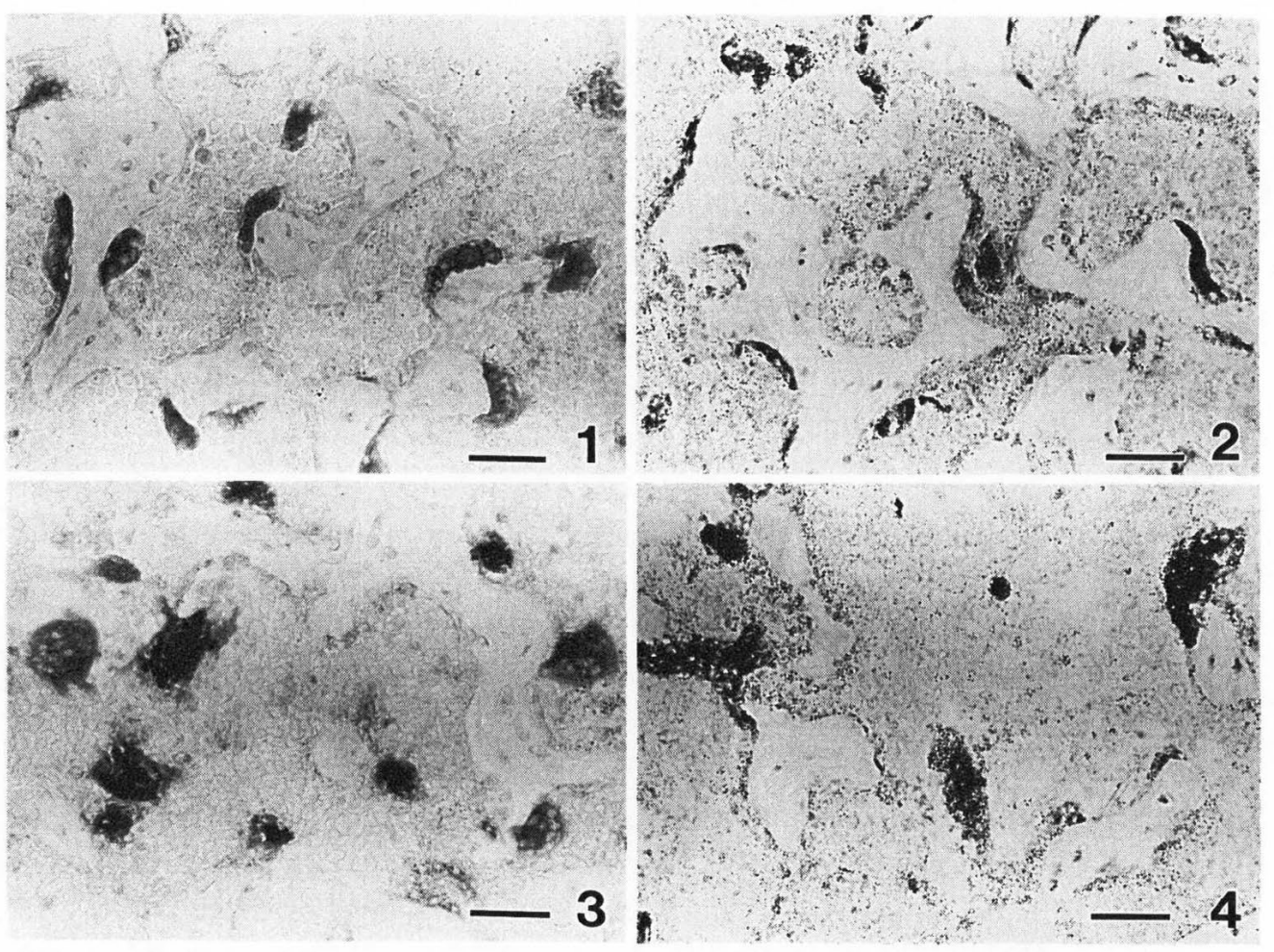

Figs. 1 and 2. The enzyme activity of osteoclasts in medullary bone before the culturing. $\times 300$. Bars $=30 \mu \mathrm{m}$. Fig. 1 . Osteoclasts exhibit moderate ACP activity. BARKA method. Fig. 2. Osteoclasts exhibit moderate SDH activity. BARKA and ANDERSON method.

Figs. 3 and 4. The enzyme activity of osteoclasts in medullary bone cultured in the presence of PTH for 6 hours. $\times 300$. Bars $=30 \mu \mathrm{m}$. Fig. 3 . Osteoclasts show strong ACP activity. BARKA method. Fig. 4. Osteoclasts show strong SDH activity. BARKA and ANDERSON method. 

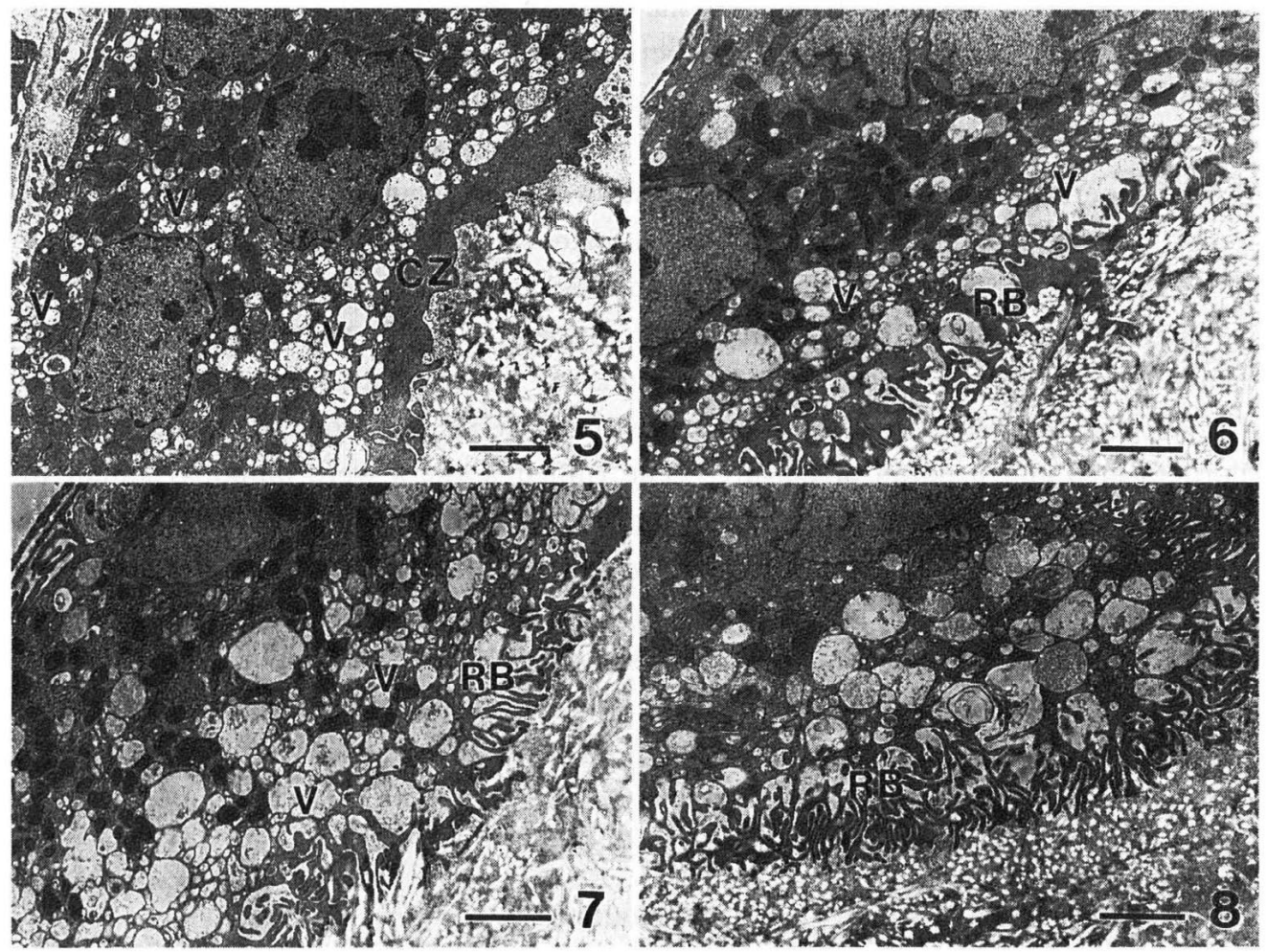

Fig. 5. An osteoclast on medullary bone before the culturing. The osteoclast lacks ruffled borders and has clear zones $(\mathrm{CZ})$ at the peripheral cytoplasm apposed to the bone. Numerous small vacuoles (V) are observed throughout the cytoplasm. $\times 4600$. Bar $=2 \mu \mathrm{m}$.

Fig. 6. An osteoclast on medullary bone at 3 hours in culturing with PTH. The osteoclast has bulbous, poorly-developed ruffled borders (RB), similar in structure to clear zones. Numerous vacuoles (V) exist under the ruffled borders. $\times 4600 . \quad$ Bar $=2 \mu \mathrm{m}$.

Fig. 7. An osteoclast on medullary bone at 12 hours in culturing with PTH. The osteoclast has long, slender, well-developed ruffled borders (RB). Numerous large vacuoles (V) are easily observed under the ruffled borders. $\times 4800$. Bar $=2 \mu \mathrm{m}$.

Fig. 8. An osteoclast on medullary bone at 24 hours in culturing with PTH. The osteoclast has well-developed ruffled borders (RB). The ruffled borders are more developed than those at other culture periods. $\times 4800$. Bar $=2 \mu \mathrm{m}$.

\section{Results}

\section{Effect of PTH on the enzyme activity of osteoclasts in cultured medullary bone}

The enzyme activity of osteoclasts in medullary bone cultured in both the presence and absence of PTH for 24 hours is shown in Table 1. Before the culturing, osteoclasts on the surface of medullary bone exhibited moderate ACP and SDH activity and strong LDH activity (Figs. 1 and 2). Throughout the culture period the enzyme activity was maintained in the absence of PTH. Osteoclasts cultured in the presence 
of PTH, however, showed strong enzyme activity of ACP and SDH after 3 hours of culture (Figs. 3 and 4), and the enzyme activity did not change thereafter.

Effect of PTH on the ultrastructure of osteoclasts in cultured medullary bone

Before the culturing, osteoclasts were observed on the medullary bone surface. These general ultrastructures of osteoclasts were the same as those of the previous report (Sugiy AmA and KusuhARA, 1993), i.e. the osteoclasts lacked ruffled borders and had clear zones at the peripheral cytoplasm apposed to the bone. Also, numerous small vacuoles were scattered throughout the cytoplasm (Fig. 5). In the absence of PTH, the characteristics of these osteoclasts did not change throughout the culture period. As for the medullary bone cultured in the presence of PTH, some osteoclasts had ruffled borders at 3 and 6 hours of culture. The ruffled borders were bulbous, similar in structute to clear zones, poorly developed. In addition, the scattered vacuoles decreased in number and many vacuoles were concentrated under the ruffled borders (Fig. 6). At 12 hours of culture, the number of osteoclasts with ruffled borders increased. The ruffled borders were long, slender, and well developed. Its area was wider than that at 3 and 6 hours of culture. Numerous large vacuoles were observed under the ruffled borders (Fig. 7). At 24 hours of culture, almost all osteoclasts had well-developed ruffled borders, and the ruffled borders were more developed as compared with those at other culture periods (Fig. 8).

\section{Discussion}

In the present study, the enzyme activity of $\mathrm{ACP}$ and $\mathrm{SDH}$ in osteoclasts increased after the culturing with PTH. It has been suggested that osteoclasts synthesize lysosomal enzymes and secrete them beneath ruffled borders where osteoclastic resorption of organic bone matrix occurs (for a review, see PIERCE et al., 1991). The synthesis of lysosomal enzymes is regulated by some calcium regulating hormones (VAES, 1970), especially PTH which stimulates the synthesis and the secretion of lysosmal enzymes in osteoclasts (VAEs, 1968 ; LuChT and MaunsBach, 1973 ; EILON and RaIsz, 1978). The $\mathrm{ACP}$ is known as a lysosmal enzyme, and its activity is used to be a marker of bone resorption (CABRINI, 1961). In chicken medullary bone, the activity of SDH and LDH as well as ACP changes during the egg-laying cycle (Kusuhara, 1975), i.e. ACP and SDH activity is strong during the resorptive phase of the bone. In the present study, ACP and SDH activity in osteoclasts increased after the culturing in the presence of PTH at the same rate as in vivo, reported previously (KUSUHARA, 1975). In other cases, for example fetal rat bones, stimulation of bone resorption by PTH is accompanied by an increase in the size of osteoclasts and their ruffled borders (Holtrop et al., 1979). There is a relationship between the increased resorption in fetal bones in organ culture and the increase of osteoclastic activity as manifested by an increase in ruffled borders (Holtrop et al., 1974 ; KInG et al., 1978). In the present study, ruffled borders appeared, and the area of the ruffled borders increased with culturing in the presence of PTH. These results confirmed that PTH stimulates osteoclastic bone resorption in medullary bone during the formative phase of the bone.

The effect of PTH is thought to be indirect and mediated through a hormonal 
factor produced by the osteoblasts or the other cells residing in bone (McSHEEHY and Chambers, 1986 ; Teti et al., $1991 \mathrm{a})$. On the other hand, Tetr et al. (1991 b) and AgARWALA and GAY (1992) demonstrated that avian osteoclasts possess PTH-binding sites, and PTH may directly stimulate osteoclastic bone resorption. In this paper, however, it is unknown whether the effect of PTH on osteoclasts is direct or indirect, because, in this organ culture system, intact osteoblasts existed for this culturing period (Sugry ama et al., 1991, 1992). Nevertheless, our results in this report represented the PTH stimulation of osteoclastic bone resorption in medullary bone. In addition, the results after each culture periods with PTH were similar to the previous results in vivo (Sugiyama and Kusuhara, 1993), indicating that the appearance and the development of ruffled borders by PTH is the same as that during the egg-laying cycle.

Recently, we demonstrated that calcitonin, one of the calcium regulating hormones, in hibits the osteoclastic bone resorption in the medullary bone of laying hens during the resorptive phase of the bone, suggesting that calcitonin is one of factors which regulate osteoclastic bone resorption in medullary bone during the egg-laying cycle (Sugiyama et al., 1993). In consideration of the previous report and these results, it is suggested that osteoclastic resorption of the medullary bone during the egglaying cycle is regulated by both calcitonin and PTH.

\section{Acknowledgment}

The synthetic human parathyroid hormone (hPTH1-34) was generously supplied by Asahi Kasei Co. Ltd.

\section{References}

Agarwala, N. and C.V. GaY (1992) Specific binding of parathyroid hormone to living osteoclasts. Journal of Bone and Mineral Research, $7: 531-539$.

BARKA, T. (1960) A simple azo-dye method for histochemical demonstration of acid phosphatase. Nature, $187: 248$.

Barka, T. and P.J. Anderson(1963) Histochemistry, 1st ed., pp. 312-318. Hoeber Medical Division Harper and Row Publisher, New York.

de Bernard, B., N. Stagni, R. Camerotto, F. Vittur, M. Zanetti, A. Zambonin Zallone and A. Teti (1980) Influence of calcium depletion on medullary bone of laying hens. Calcified Tissue International, $32: 221-228$.

CABRINI, R.L. (1961) Histochemistry of ossification. International Review of Cytology, 11 : 283-306.

EILON, G. and L.G. RAISZ (1978) Comparison of the effects of stimulators and inhibitors of resorption on the release of lysosomal enzymes and radioactive calcium from fetal bone in organ culture. Endocrinology, 103 : 1969-1975.

Garabedian, M., M.F. Holick, H.F. Deluca and I.T. Boyle(1972) Control of 25-hydroxycholecalciferol metabolism by parathyroid glands. Proceedings of the National Academy of Sciences of the United States of America, 69 : 1673-1676.

Holtrop, M.E., A. Cox, M.B. Clark, M.F. Holick and C.S. Anast (1981) 1,25-dihydroxycholecalciferol stimulates osteoclasts in rat bones in the absence of parathyroid hormone. Endocrinology, $108: 2293-2301$.

Holtrop, M.E., G.J. KING, K.A. Cox and B. ReIT (1979) Time-related changes in the ultrastructure of osteoclasts after injection of patathyroid hormone in young rats. Calcified Tissue Internation. al, $27: 129-135$.

Holtrop, M.E. and L.G. RaISZ (1979) Comparison of the effects of 1,25-dihydroxycholecalciferol, 
prostaglandin $\mathrm{E}_{2}$, osteoclast-activating factor with parathyroid hormone on the ultrastructure of osteoclasts in cultured long bones of fetal rats. Calcified Tissue International, 29 : 201-205.

Holtrop, M.E., L.G. RAISz and H.A. Simmons(1974) The effets of parathyroid hormone, colchicine, and calcitonin on the ultrastructure and the activity of osteoclasts in organ culture. Journal of Cell Biology, $60: 346-355$.

King, G.J., M.E. Holtrop and L.G. Raisz (1978) The relation of ultrastructural changes in osteoclasts to resorption in bone cultures stimulated with parathyroid hormone. Metabolic Bone Diseases \& Related Research, $1: 67-74$.

Kusuhara, S. (1975) Enzymohistochemical studies on the formation and resorption of bones in laying hens. Japanese Journal of Zootechnical Science, 46 : 277-282.

Kusuhara, S. (1982) Influence of parathyroid hormone on the resorption of chicken medullary bone developed by the administration of sexual hormones. Japanese Journal of Zootechnical Science, 53 : 332-337.

LuCht, U. and A.B. Maunsbach (1973) Effect of parathyroid hormone on osteoclasts in vivo: an ultrastructural and histochemical study. Zeitschrift für Zellforschung und Mikroskopische Anatomie, $141: 529-544$.

Luck, M.R., B.A. Sommerville and C.G. Scanes (1980) The effects of egg-shell calcification on the response of plasma calcium activity to parathyroid hormone and calcitonin in the domestic fowl (Gallus Domesticus). Comparative Biochemistry and Physiology, 65A : 151-154.

McSheeny, P.M.J. and T.J. Chambers (1986) Osteoblast-like cells in the presence of parathyroid hormone release soluble factor that stimulates osteoclastic bone resorption. Endocrinology, 119 : 1654-1659.

MiLLER, S.C. (1977) Osteoclast cell-surface changes during the egg-laying cycle in Japanese quail. Journal of Cell Biology, 75 : 104-118.

MiLlER, S.C. (1978) Rapid activation of the medullary bone osteoclast cell surface by patathyroid hormone. Journal of Cell Biology, $76: 615-618$.

MiLlER, S.C. (1981) Osteoclast cell-surface specializations and nuclear kinetics during egg-laying in Japanese quail. American Journal of Anatomy, $162: 35-43$.

MilleR, S.C. (1985) The rapid appearance of acid phosphatase activity at the developing ruffled border of parathyroid hormone activated medullary bone osteoclasts. Calcified Tissue International, $37: 526-529$.

MilleR, S.C., B.M. Bowman and R.L. Myers (1984) Morphological and ultrastructural aspects of the activation of avian medullary bone osteoclasts by parathyroid hormone. Anatomical Record, $208: 223-231$.

Mueller, W.J., R. Schraer and H. Schraer (1964) Calcium metabolism and skeletal dynamics of laying pullets. Journal of Nutrition, $84: 20-26$.

Pierce, A.M., S.Lindskog and L. Hammarstrom (1991) Osteoclasts : structure and function. Electron Microscopy Reviews, $4: 1-45$.

Singh, R., C.J. Joyner, M.J. Peddie and T.G. TAylor(1986) Changes in the concentrations of parathyroid hormone and ionic calcium in the plasma of laying-hens during the egg cycle in relation to dietary deficiencies of calcium and vitamin D. General and Comparative Endocrinology, $61: 20-28$.

SugiYama, T. and S. Kusuhara (1993) Ultrastructural changes of osteoclasts on hen medullary bone during the egg-laying cycle. British Poultry Science, 34 : 471-477.

Sugiyama, T., T. Ohashi, S. Nimmura, S. Kusuhara and K. Ishida (1991) Osteoclasts and osteoblasts in organ-cultured medullary bones of laying hens. Bulletin of the Faculty of Agriculture, Niigata University, $43:$ 149-155.

Sugiyama, T., T. OHASHi and S. Kusuhara (1992) Electron microscopic observations of osteoclasts and osteoblasts in cultured medullary bones of laying hens. Animal Science and Technology (Jpn), $63: 468-473$.

Sugiyama, T., T. Ohashi and S. Kusuhara (1993) Inhibition of osteoclastic bone resorption by calcitonin in the cultured medullary bone of laying hens. Japanese Poultry Science, 30 : 16-23.

Teti, A., M. Grano, S. Colucci, F.P. Cantatore, M.C. Loperfido and A. Zambonin Zallone (1991 a) 
Osteoblast-osteoclast relationships in bone resorption : osteoblasts enhance osteoclast activity in a serum-free co-culture system. Biochemical and Biophysical Research Communications, $179: 634-640$.

Teti, A., R. Rizzoli and A. Zambonin Zallone (1991 b) Parathyroid hormone binding to cultured avian osteoclasts. Biochemical and Biophysical Research Communications, 174 : 1217-1222.

VAES, G. (1968) On the mechanisms of bone resorption : the action of parathyoid hormone on the excretion and synthesis of lysosomal enzymes and on the extracellular release of acid by bone cells. Journal of Cell Biology, 39 : 676-697.

VAES, G. (1970) Enzymatic and other biochemical events accompanying bone resportion in tissue culture. Calcified Tissue Research, 4 (supplement) : 57-60.

VAN DE VELDE, J. P., N. Loveridge and J.P.W. Vermeiden (1984 a) Parathyroid hormone responses to calcium stress during eggshell calcification. Endocrinology, 115 : 1901-1904.

VAN DE Velde, J.P., J.P.W. Vermeiden, J.J.A. Touw and J.P. VeldhuiJzen (1984 b) Changes in acitivity of chicken medullary bone cell populations in relation to the egg-laying cycle. Metabolic Bone Diseases \& Related Research, 5 : 191-193.

WendelaAR Bonga, S.E. and P.K.T. PANG (1991) Control of calcium regulating hormones in the vertebrates : parathyroid hormone, calcitonin, prolactin, and stanniocalcin. International Review of Cytology, $128: 139-213$.

\title{
副甲状腺ホルモンが培養骨䯣骨の破骨細胞に及ぼす影響
}

\author{
杉山稔恵・楠原征治* \\ 新潟大学大学院自然科学研究科, \\ * 新潟大学農学部, 新潟市 $950-21$
}

卵が卵管の卵白分泌部に存在し，骨吸収が停止してい る時期の産卵鶏骨䯣骨を副甲状腺ホルモン添加培地で培 養し，破骨細胞の酵素活性と微細構造を観察した。副甲 状腺ホルモン無添加の培養骨髄骨では, 破骨細胞は, 培 養前と同様に中等度の酸性ホスファターゼ (ACP) およ びコハク酸脱水素酵素 $(\mathrm{SDH})$ 活性を示し, 強い乳酸脱 水素酵素 $(\mathrm{LDH})$ 活性を示した。これらの破骨細胞には, 波状縁は認められなかった。一方, 副甲状腺ホルモンを 添加した培養骨鲔骨では, 培養後 3 時間で破骨細胞の
$\mathrm{ACP}$ および SDH 活性が増加し，細胞質の骨基質側に波 状縁が認められた。さらに，培養後 12 時間では，波状縁 の面積が増加し，培養後 24 時間では，ほぼ全ての破骨細 胞が発達した波状縁を有していた。以上の結果から，副 甲状腺ホルモンは, 卵が卵白分泌部に存在する時期にお ける破骨細胞の骨吸収を促進することが示唆された。

（家禽会誌，31：392-399，1994） キーワード : 破骨細胞, 副甲状腺ホルモン, 骨髄骨, 培 養, 産卵觅 